\title{
ANTROPOLOGIA KATOLICKA W PERSPEKTYWIE EKOLOGICZNEJ. STUDIUM PASTORALNE W ŚWIETLE ENCYKLIKI LAUDATO SI
}

Antropologia, jako interdyscyplinarna dziedzina wiedzy, korzysta z nauk humanistycznych, społecznych i przyrodniczych. Jak wskazuje sam termin, jest to nauka o człowieku jako jednej, jedynej, niepowtarzalnej „osobie”. Własne spojrzenie na człowieka ma również religia chrześcijańska, której antropologia korzysta z osiągnięć teologii, filozofii, religiologii. Natomiast antropologia katolicka jest odrębną nauką, której podstawowym źródłem prawdy o człowieku jest objawienie i Magisterium Kościoła.

Punktem wyjścia w antropologii katolickiej jest teza, że najpierw należy poznać Boga, który objawił się w Osobie Syna Bożego, Jezusa Chrystusa, aby następnie pod natchnieniem Ducha Świętego ${ }^{1}$ zdobywać wiedzę o człowieku. Takie poznanie jest możliwe w ramach teologii, której nikt nie może uprawiać ,jako zbioru swoich tylko poglądów, ale musi być świadom, że pozostaje w szczególnej łączności z tym posłannictwem Prawdy, za którą odpowiedzialny jest Kościół".2 Antropologię katolicką cechuje zatem eklezjalność, czyli

1 „Jeżeli zaś chodzi o «życie wiary», to Sobór Watykański II wyjaśnia, że «ogół wiernych, mających namaszczenie od Ducha Świętego, nie może zbłądzić w wierze» $\mathrm{i}$ «tę szczególną swoją własność ujawnia przez nadprzyrodzony zmysł wiary całego ludu, gdy - poczynając od biskupów aż po ostatniego z wiernych świeckich - ujawnia on powszechną zgodność w sprawach wiary i obyczajów»"; Ko ng re ga c j a $\mathrm{Na} \mathrm{u} \mathrm{k} \mathrm{i} \mathrm{W} \mathrm{i} \mathrm{a} \mathrm{y,} \mathrm{Instrukcja} \mathrm{o} \mathrm{powołaniu} \mathrm{teologa} \mathrm{w} \mathrm{Kościele}$ „Donum veritatis” (24 maja 1990), Watykan 1990, nr 4.

2 J a n Paweł II, Encyklika Redemptor hominis (4 marca 1979), Watykan 1979, nr 19. W filozofii myśl jednego człowieka może służyć postępowi ludzkości. 
wierność tradycji Ludu Bożego z całym jego bogactwem i wielorakością wiedzy i kultur połączonych jednością wiary. ${ }^{3}$

W kontekście współczesnego postępu cywilizacyjnego, rozwoju nauki i wszechobecności nowoczesnych technologii, łącznie ze sztuczną inteligencją, jawi się ważne pytanie: Jak dzisiaj powinna rozwijać się antropologia katolicka? Jan Paweł II, analizując sytuację ludzi wierzących, w posynodalnej adhortacji Ecclesia in Europa, podkreślił, że dzisiaj „,W wielu sferach publicznych łatwiej jest deklarować się jako agnostycy niż jako wierzący; odnosi się wrażenie, że niewiara jest czymś naturalnym, podczas gdy wiara wymaga uwierzytelnienia społecznego, które nie jest ani oczywiste, ani przewidywalne". ${ }^{4}$ Natomiast Benedykt XVI, już jako papież senior, potwierdził słuszność tych twierdzeń, gdyż w Ostatnich rozmowach

Jednak prawdziwe bogactwo myśli ludzkiej rodzi się ze spotkania filozofii z teologią i z wzajemnej wymiany ich dorobku. Teologia, otrzymawszy w darze otwartość i oryginalność, dzięki którym może istnieć jako nauka wiary, z pewnością nakłoniła rozum, by pozostał otwarty na radykalną nowość, jaką zawiera w sobie Boże objawienie. Przyniosło to niewątpliwą korzyść filozofii, gdyż dzięki temu mogła ona otworzyć nowe horyzonty, odsłaniające przed nią kolejne zagadnienia, które rozum ma coraz głębiej poznawać; J a n P a w e 1 II, Encyklika Fides et ratio (14 września 1998), Watykan 1998, nr 101.

3 Tamże. „[Galileusz] wyraźnie oświadczył, że dwie prawdy, tj. wiara i nauka, nie mogą nigdy pozostawać z sobą w sprzeczności. «Pismo Święte i przyroda pochodzą od Słowa Bożego. Pierwsze jako podyktowane przez Ducha Świętego, druga zaś jako wierna wykonawczyni nakazów Bożych» - pisał w swym liście do ojca Benedetto Castellego z dnia 21 grudnia 1613 r. A II Sobór Watykański nie naucza inaczej, ale posługuje się podobnymi słowami, kiedy mówi: «Badanie metodyczne we wszelkich badaniach naukowych, jeżeli tylko prowadzi się je (...) z poszanowaniem norm moralnych, naprawdę nigdy nie będzie się sprzeciwiać wierze, sprawy bowiem świeckie i sprawy wiary wywodzą swój początek od tego samego Boga» (Gaudium et spes, 36). Galileusz odczuwał w swoich naukowych badaniach obecność Boga, który go pobudzał, uprzedzał i wspomagał w jego intuicjach, działając w głębi jego umysłu”; J a n P aw e ł II, Przemówienie do Papieskiej Akademii Nauk (10 maja 1979), w: Program komputerowy „Nauczanie Kościoła Katolickiego”, Kraków 2003, nr 2.

4 Te n że, Adhortacja apostolska Ecclesia in Europa (28 czerwca 2003), Watykan 2003, nr 7. 
powiedział: „To, że nie przystajemy już do współczesnej kultury, a chrześcijańskie wzorce przestały być decydującym wskazaniem, to oczywiste. Obecnie żyjemy w ramach pozytywistycznej i agnostycznej obyczajowości, która staje się coraz bardziej nietolerancyjna wobec chrześcijaństwa. Stąd też społeczeństwo Zachodu, w każdym razie Europa, po prostu nie będzie chrześcijańskie". ${ }^{5}$

Wobec takich zagrożeń współczesnym katolikom potrzebna jest nowa antropologia katolicka, w której znajdą zrozumiałą odpowiedź na odwieczne pytania o sens życia i śmierci, o godność osoby ludzkiej, a przede wszystkim o sens wiary w Boga Stworzyciela i Zbawiciela. Wychodząc od tych pytań, „rozum jeszcze mocniej odczuł pragnienie coraz szerszej i coraz głębszej wiedzy. W rezultacie zbudowano złożone systemy myślowe, które zaowocowały rozwojem różnych dziedzin wiedzy, sprzyjając postępowi w kulturze i w dziejach. Antropologia, logika, nauki przyrodnicze, historia, język - w pewien sposób cały obszar wiedzy został objęty tym procesem. Pozytywne osiągnięcia nie powinny jednak przesłaniać faktu, że tenże rozum, skupiony jednostronnie na poszukiwaniu wiedzy o człowieku jako podmiocie, wydaje się zapominać, iż powołaniem człowieka jest dążenie do prawdy, która przekracza jego samego. Bez odniesienia do niej każdy zdany jest na samowolę ludzkiego osądu, a jego istnienie jako osoby oceniane jest wyłącznie według kryteriów pragmatycznych, opartych zasadniczo na wiedzy doświadczalnej, pod wpływem błędnego przeświadczenia, że wszystko powinno być podporządkowane technice. Rezultat jest taki, że - zamiast wyrażać jak najlepiej dążenie do prawdy - rozum chyli się ku samemu sobie pod brzemieniem tak rozległej wiedzy, przez co z dnia na dzień staje się coraz bardziej niezdolny do skierowania uwagi ku wyższej rzeczywistości i nie śmie sięgnąć po prawdę bytu. Nowoczesna filozofia zapomniała, że to byt winien stanowić przedmiot jej badań, i skupiła się na poznaniu ludzkim. Zamiast wykorzystywać zdolność

5 B e n e d y k t XVI, Ostatnie rozmowy, Kraków 2016, s. 269. 
człowieka do poznania prawdy, woli podkreślać jego ograniczenia oraz uwarunkowania, jakim podlega". ${ }^{6}$

Niebezpieczeństwo dochodzenia do fałszywych wniosków zagraża również badaniom antropologicznym, dlatego antropologa katolickiego obowiązuje ta sama zasada, co teologa, którego szczególnym zadaniem jest zdobywanie, w łączności z Urzędem Nauczycielskim, coraz głębszego zrozumienia słowa Bożego zawartego w natchnionym Piśmie Świętym i przekazanego przez żywą Tradycję Kościoła. Wiara wymaga intelektualnej podbudowy, dlatego ze swojej natury dąży do rozumienia, aby objawić człowiekowi prawdę o jego przeznaczeniu i drogę do jego osiągnięcia. Dlatego jeśli nawet wyrażenie w słowach prawdy objawionej przekracza ludzkie możliwości i jeśli pojęcia są niedoskonałe wobec jej niezgłębionej wielkości, to jednak dla rozumu, będącego danym przez Boga narzędziem poznawania prawdy, stanowi ona zaproszenie do wejścia w jej Światło, które umożliwi zrozumienie tego, w co uwierzył. Antropologia katolicka, podobnie jak teologia, jest więc taką nauką, która odpowiadając na wezwanie prawdy, poszukuje zrozumienia wiary. ${ }^{7}$

Dlatego też współcześni katolicy powinni na nowo zainteresować się antropologią katolicką. Jest to tym bardziej konieczne, że we współczesnym społeczeństwie tworzone są takie koncepcje człowieka, które oddalają się od prawdy i wykluczają Boga w przekonaniu, iż w ten sposób zostaje potwierdzony prymat człowieka w imię jego rzekomej wolności oraz pełnego i swobodnego rozwoju. W ten sposób ideologie te pozbawiają człowieka jego konstytutywnego wymiaru osoby stworzonej na obraz i podobieństwo Boga. To poważne okaleczenie jest dziś prawdziwym zagrożeniem dla człowieka, prowadzi bowiem do postrzegania go bez żadnego odniesienia do transcendencji. ${ }^{8}$ Papież Franciszek, uznając te zagrożenia związane

6 J a n P aw e 1 II, Encyklika Fides et ratio, nr 5.

7 Kongregacja Nauki Wiary, Instrukcja o powołaniu teologa wościele Donum veritatis, $\mathrm{nr} 6$.

8 Jan Paw eł II, Przesłanie do uczestników Zgromadzenia Plenarnego Papieskiej Rady ds. Kultury Chrześcijański humanizm (19 listopada 1999), https:// 
z osobą człowieka za ważne wyzwanie również dla ochrony środowiska, umieścił w encyklice Laudato si nowe impulsy o charakterze ekologicznym do uwspółcześnienia katolickiej antropologii. Jego nauczanie koncentruje na nowo badania antropologiczne na poszukiwaniu miejsca człowieka w stworzeniu i wynikającymi z tego konsekwencjami.

\section{Katolicki a „nowoczesny” antropocentryzm}

Zgodnie z katolickim antropocentryzmem, tak jak całe stworzenie, tak i człowiek, który jest objęty procesami ewolucyjnymi, niesie ze sobą pewną nowość, której nie da się wyjaśnić przez ewolucję oraz inne systemy otwarte. Każdy człowiek ma i reprezentuje tożsamość osobistą, zdolną do wejścia w relacje i dialog z samym Bogiem i z innymi osobami. Zdolność człowieka do refleksji, rozumowania, kreatywności, interpretacji, twórczości artystycznej i inne oryginalne możliwości ukazują jego wyjątkowość, która wykracza poza dziedzinę fizyczną i biologiczną życia. Nowość jakościowa, jaką oznacza powstanie bytu osobowego $\mathrm{w}$ ramach materialnego wszechświata, zakłada bezpośrednie działanie Boga, który, stwarzając człowieka, uzdalnia i powołuje go jednocześnie do nawiązywania relacji osobowych. Antropologia katolicka, ujmowana w perspektywie ekologicznej, opierając się na Biblii, Tradycji i Magisterium, uznaje zatem osobę człowieka za podmiot, którego nigdy nie można redukować do kategorii przedmiotu. ${ }^{9}$

Podmiotowość osoby ludzkiej ukierunkowuje człowieka na innych ludzi, z którymi łączą go różnorakie relacje. Dotyczy to również jego relacji z całym stworzeniem. $Z$ tej racji w antropologii katolickiej kryzys ekologiczny traktuje się jako zewnętrzny przejaw problemów związanych z poszanowaniem godności osobowej człowieka, a także szeroko rozumianego kryzysu etycznego, kulturowego i duchowego

opoka.org.pl/biblioteka/W/WP/jan_pawel_ii/przemowienia/pr_kultury_19111999. html (dostęp: 25 III 2019), nr 2.

9 Fr a n c is z e k, Encyklika Laudato si (24 maja 2015), Watykan 2015, nr 81. 
nowoczesności. Konsekwentnie więc antropolodzy katoliccy twierdzą, że uzdrowienie relacji człowieka z przyrodą i środowiskiem naturalnym jest niemożliwe bez uznania godności każdej osoby ludzkiej i uzdrowienia wszystkich podstawowych relacji międzyludzkich. Oznacza to, że otwarcie człowieka na „ty”, uzdolniające go do poznania, umiłowania i dialogu, dookreśla wielką jego szlachetność. To ona umożliwia mu właściwą relację z rzeczywistością stworzoną przy zachowaniu społecznego wymiaru istoty ludzkiej, a także jej wymiaru transcendentnego, jej otwartości na Boże „Ty”. W koncepcji ekologicznej antropologii katolickiej podkreśla się więc, że o jakości relacji człowieka ze środowiskiem, decyduje jego związek z Bogiem i relacje z innymi ludźmi. Według Franciszka podważanie tej prawdy prowadzi do romantycznego indywidualizmu ukrytego pod maską ekologicznego piękna i duszącego zamknięcia się w immanencji. ${ }^{10}$

W opozycji do antropologii katolickiej jawi się dzisiaj antropologia oparta na nowoczesnym antropocentryzmie, który doprowadził do postawienia czynników technicznych ponad człowiekiem. Przyczyną tego stanu rzeczy jest to, że człowiek nie postrzega już natury ,jako zawsze obowiązującej normy, ani tym bardziej jako życiowego schronienia. Spogląda on na nią bez żadnych gotowych założeń, rzeczowo, jako na miejsce i materiał swojej twórczości, której wszystko poświęca, nie dbając o to, co z niej wyniknie". ${ }^{11} \mathrm{~W}$ ten sposób osłabia się wartość, jaką świat ma sam w sobie. Wynikają z tego poważne konsekwencje. Jeśli bowiem człowiek nie odkrywa swojego prawdziwego miejsca, to również nie rozumie właściwie siebie i doprowadza do zaprzeczenia własnej naturze. Dlatego w antropologii katolickiej przyjmuje się zasadę, że „nie tylko ziemia została dana człowiekowi przez Boga, aby używał jej z poszanowaniem pierwotnie zamierzonego dobra, dla którego została mu ona dana, ale również człowiek jest dla siebie samego darem otrzymanym od Boga

Tamże, nr 119.

1 R. G u a r d i n i, Koniec czasów nowożytnych. Świat i osoba. Wolność, łaska, los, Kraków 1969, s. 53. 
i dlatego musi respektować naturalną i moralną strukturę, w jaką został wyposażony". ${ }^{2}$

Odrzucenie w antropologii nowoczesnej relacji człowieka z Bogiem prowadzi do fałszywego antropocentryzmu, który zagraża przede wszystkim samemu człowiekowi, zaburza jego wyczucie wspólnotowości i skazuje na niepowodzenia próby wzmocnienia więzi i relacji społecznych. Z tego względu w antropologii katolickiej zwraca się szczególną uwagę na swoisty oksymoron, który pokazuje, że ograniczenia rzeczywistości ziemskiej mogą stanowić jednocześnie dla konkretnego człowieka możliwości bardziej zdrowego i owocnego rozwoju ludzkiego i społecznego. Nieodpowiednia prezentacja tych podstawowych założeń antropologii katolickiej w ujęciu ekologicznym doprowadziła do promocji błędnego przekonania na temat relacji człowieka ze światem. Na skutek tego w antropologii nowoczesnej pojawiło się więc prometejskie marzenie panowania nad światem, które wywołało wrażenie, że troska o naturę jest sprawą ludzi słabych. ${ }^{13}$

Antropologia katolicka stoi w wyraźnej opozycji do antropologii nowoczesnej przede wszystkim na płaszczyźnie sporu ideologicznego. Chodzi o to, że wielu współczesnych antropologów ulega swoistej egzaltacji technokratycznej, która nie przyznaje innym istotom właściwej im wartości, aż po odmowę jakiejkolwiek szczególnej wartości osobie ludzkiej. Dlatego antropologowie katoliccy podkreślają, że na pierwszym miejscu należy dowartościować człowieczeństwo, gdyż bez przyjęcia bezwarunkowo określonej godności osoby człowieka nie da się utworzyć jego nowej relacji z naturą. Nie ma zatem prawdziwej ekologii bez właściwej antropologii. Gdy osoba ludzka uważana jest jedynie za jakiś kolejny byt pośród innych, pochodzący jakby z gry losowej lub fizycznego determinizmu, ,powstaje zagrożenie,

12 J a n P aw eł II, Encyklika Centesimus annus (1 maja 1991), Watykan 1991, nr 38 .

13 F r a n c is z e k, Encyklika Laudato si, nr 116. Prawidłową interpretacją pojęcia człowieka jako ,pana” wszechświata jest rozumienie go w sensie „odpowiedzialnego zarządcy". 
że świadomość odpowiedzialności ulegnie w sumieniach osłabieniu". ${ }^{14}$ Fałszywym rozwiązaniem byłaby również zamiana nowoczesnego antropocentryzmu na „biocentryzm”, bo oznaczałoby to dokładanie nowego nieładu, który nie tylko nie rozwiąże problemów związanych z osobą człowieka i jej miejscem w stworzeniu, ale przysporzy nowych. W ekologicznie ukierunkowanej antropologii katolickiej podkreśla się więc, że nie można wymagać od człowieka zaangażowania w świat, jeśli nie uznaje się i nie podkreśla jednocześnie jego związku z Bogiem, który jest źródłem szczególnych zdolności poznawania, woli, wolności i odpowiedzialności. ${ }^{15}$

Drugim ważnym obszarem konfrontacji antropologii katolickiej ze współczesnym antropocentryzmem jest stosunek człowieka do postępu cywilizacyjnego. W antropologii nowoczesnej przyjmuje się fałszywe założenie, według którego postęp to wzrost mocy dającej większe bezpieczeństwo, pożytek, dobrobyt, więcej sił żywotnych, pełnię wartości. Doświadczenie pokazuje jednak, że współczesny człowiek nie został wychowany tak, by umiał się posługiwać właściwie swą mocą ${ }^{16}$ gdyż ogromnemu wzrostowi technologicznemu nie towarzyszy rozwój istoty ludzkiej w wymiarze etyczno-moralnym w odniesieniu zwłaszcza do odpowiedzialności, wartości i sumienia. Wbrew założeniom antropologii nowoczesnej rzeczywistość, dobro, prawda i piękno nie wypływają spontanicznie z samej mocy tech-

14 B e ne dy k t XVI, Orędzie na Światowy Dzień Pokoju (8 grudnia 2009), http://w2.vatican.va/content/benedict-xvi/pl/messages/peace/documents/hf_ben-xvi_mes_20091208_xliii-world-day-peace.html (dostęp: 25 III 2019), nr 2.

${ }^{15}$ Fra n c is z e k, Encyklika Laudato si, nr 118. Życie ludzkie jest dialogiem między Bogiem a człowiekiem, który dokonuje się w czynach. W dialogu tym świat materialny i historia umieszczone są przez Boga między Nim a ludźmi jako przekład Jego wewnętrznego przemawiania do nich. Ten świat i historia są również środkami, w których i dzięki którym uwaga człowieka jest przyciągana do tego wewnętrznego głosu Boga, ale jednocześnie są one środowiskiem, w którym człowiek ma możność udzielania odpowiedzi na posłannictwo, które stworzenie nałożyło na niego; C. J. v a n d e r P o e l, W poszukiwaniu wartości ludzkich, Warszawa 1979, s. 75.

16 R. G u a r d i n i, Koniec czasów nowożytnych. Świat i osoba. Wolność, taska, los, s. 68 . 
nologii i ekonomii. Faktem jest natomiast, że każda epoka dąży do rozwijania ograniczonej samoświadomości swoich ograniczeń. $Z$ tego względu jest dziś możliwe, że ludzkość nie dostrzega powagi pojawiających się przed nią wyzwań i ciągle wzrasta możliwość, że człowiek będzie źle używał swej mocy, kiedy nie jest ona „podporządkowana obowiązującym normom regulującym wolność, a jedynie pozornie koniecznym normom, mianowicie pożytku i zabezpieczenia jutra". ${ }^{17}$

Ważną kwestią antropologiczną jest również dookreślenie godności osobowej człowieka jako istoty świadomej i wolnej, jednak nie w pełni autonomicznej. Antropologowie katoliccy mają pełną świadomość, że dzisiaj zagrożona jest przede wszystkim wolność człowieka, która ulega wypaczeniu, kiedy powierza się ją ślepym siłom podświadomości, doraźnym potrzebom, egoizmowi i brutalnej przemocy. W tym sensie jest ona zagrożona i bezbronna wobec własnej mocy, która nieustannie rośnie, nie mając właściwych narzędzi jej kontroli. W antropologii katolickiej podkreśla się zatem, że człowiek może dysponować powierzchownymi mechanizmami, ale przy tym potrzebuje odpowiednio solidnej etyki, kultury i duchowości, które rzeczywiście by ją ograniczały i utrzymywały w ryzach. ${ }^{18}$

\section{Relacje w środowisku naturalnym czlowieka}

W antropologii katolickiej, ujmowanej w perspektywie ekologicznej, bardzo ważnym elementem jest rzeczywistość historyczna czasu i przestrzeni, która warunkuje życie człowieka w środowisku naturalnym. W tej czasoprzestrzeni tworzą się i funkcjonują trzy podstawowe relacje człowieka, ściśle ze sobą związane: z Bogiem, z innymi ludźmi i z ziemią. Według Biblii z powodu grzechu te trzy istotne relacje uległy zerwaniu nie tylko zewnętrznie, ale również w samym człowieku. Harmonia między Stwórcą, ludzkością a całym stworzeniem została zniszczona, ponieważ człowiek usiłował zająć miejsce Boga (fałszywy antropocentryzm), odmawiając

17 Tamże, s. 87-88.

18 Fr a n c is z e k, Encyklika Laudato si, nr 105. 
uznania siebie za ograniczone stworzenie. $Z$ tego względu znamienne jest, że przeżywana przez św. Franciszka z Asyżu harmonia ze wszystkimi stworzeniami była interpretowana jako uzdrowienie tego zerwania. ${ }^{19}$

Przykład św. Franciszka pokazuje, że kiedy serce jest naprawdę otwarte na powszechną komunię i tworzenie relacji, to nic i nikt nie jest wykluczony z tego braterstwa. Dlatego też prawdą jest, że obojętność lub okrucieństwo wobec innych stworzeń tego świata zawsze w jakiś sposób przekłada się na sposób traktowania innych ludzi. Serce jest jedno i ta sama „bieda duchowa”, która prowadzi do znęcania się nad zwierzętami, niechybnie przejawi się w relacjach z innymi osobami. ${ }^{20}$ Żaden człowiek nie może uważać siebie za osobę naprawdę miłującą, jeśli wyklucza ze swoich zainteresowań jakąś część rzeczywistości. Wszystko jest bowiem ze sobą powiązane i dlatego wszyscy ludzie są zjednoczeni jako bracia i siostry we wspaniałej pielgrzymce, połączeni miłością, którą Bóg obdarza każde ze swoich stworzeń, miłością, która łączy każdego człowieka z bratem Słońcem i Księżycem, siostrą Rzeką, i matką Ziemią. ${ }^{21}$

Miłość do całego wszechświata, z jego różnorodnymi relacjami, powinna mieć swoje źródło w miłości do Boga, którego niewyczerpane bogactwo ukazuje stworzenie. Według św. Tomasza wielość i rozmaitość stworzenia jest dziełem zamysłu pierwszego Twórcy Boga, który chciał, aby „czego nie dostaje jednemu, dla przedstawienia dobroci Bożej, z drugiego można było uzupełnić”, ponieważ Jego dobroć „,nie może być wyczerpująco przedstawiona przez jedno stworzenie". ${ }^{22}$ Warunkiem odkrycia bogactwa stworzenia jest zatem uchwycenie różnorodność rzeczy w ich wielorakich relacjach. ${ }^{23}$ Pełne

19 Tamże, nr 66.

20 Wszelkie okrucieństwo wobec jakiegokolwiek stworzenia jest sprzeczne z godnością człowieka; por. Katechizm Kościoła Katolickiego, nr 2418.

${ }_{21}$ F r a n c i s z e k, Encyklika Laudato si, nr 92.

22 Tomasz z A kw in u, Summa Theologiae I, q. 47, art. 1.

23 Tamize, art. 2, ad. 1; art. 3. 
rozumienie znaczenia i sensu każdego stworzenia wymaga więc uznania całego, stwórczo-zbawczego planu Bożego. ${ }^{24}$

\section{Rola relacji w poznaniu czlowieka i świata}

U źródeł rozumowego poznania człowieka i świata znajdują się podstawowe pytania: „Kimże jest człowiek i jakież jest jego znaczenie? Cóż jest jego dobrem i cóż złem jego?” (Syr 18,8). Pytania te wyrażają naglącą potrzebę odnalezienia sensu istnienia zarówno na jego istotnych i decydujących etapach, jak również w chwilach najbardziej zwyczajnych. Pytania te pobudzają też rozum i wolę człowieka do poszukiwania rozwiązania, które mogłoby nadać życiu pełny sens. Kiedy zatem ,przyczyna rzeczy” poddawana jest całościowym badaniom, których celem jest poszukiwanie ostatecznej i wyczerpującej odpowiedzi, rozum ludzki dosięga swego szczytu i otwiera się przed religią. Religijność bowiem stanowi najwznioślejszy wyraz osoby ludzkiej, gdyż jest szczytem jego rozumnej natury. Wypływa ona z głębokiego dążenia człowieka do prawdy i stanowi podstawę swobodnego i osobistego poszukiwania Boskości. ${ }^{25}$

Poznanie człowieka i świata może mieć wymiar czysto rozumowy, ale w celu pełnego zrozumienia ich sensu i znaczenia dla człowieka i jego egzystencji niezbędna jest również wiara. Poszukiwanie prawdy dokonuje się bowiem nie tylko w indywidualnym zmaganiu w bibliotece czy w laboratorium, ale ma także wymiar wspólnotowy, relacyjny. Człowiek udoskonala się nie tylko przez zdobywanie teoretycznej wiedzy o prawdzie, ale także przez żywą relację z drugim człowiekiem, która wyraża się przez dar z siebie i przez wierność, uzdalniającą do złożenia siebie w darze. Dzięki

${ }^{24}$ F r a n c i s z e k, Encyklika Laudato si, nr 86. „Współzależność stworzeń jest chciana przez Boga. Słońce i księżyc, cedr i mały kwiatek, orzeł i wróbel: niezmierna rozmaitość i różnorodność stworzeń oznacza, że żadne z nich nie wystarcza sobie samemu. Istnieją one tylko we wzajemnej zależności od siebie, by uzupełniać się, służąc jedne drugim"; Katechizm Kościoła Katolickiego, nr 340.

${ }_{25}$ J a n P awe 1 II, Audiencja generalna 19 X 1983, L'Osservatore Romano, wyd. pol., 10/1983, s. 23-24. 
temu człowiek znajduje pełnię pewności w prawdzie i bezpieczeństwa w życiu. Poznanie rozumowe prawdy powinno być zatem oparte na wierze, której podstawą jest zaufanie między osobami: wierząc, człowiek zawierza prawdzie, którą ukazuje mu druga osoba. ${ }^{26}$ Do pełni prawdy dochodzi się więc dzięki innym, w dialogu z innymi i dla innych. Poszukiwanie prawdy i dzielenie się nią z innymi jest ważną posługą społeczną, do jakiej w sposób szczególny są wezwani ludzie nauki, zwłaszcza wyznający wiarę chrześcijańską. ${ }^{27}$

\section{Trójca Święta i relacje między stworzeniami}

Wzorem wszelkich relacji, w jakich funkcjonuje człowiek, jest Trójca Święta. Osoby Boskie są relacjami samoistnymi, a świat stworzony na wzór Boga jest siecią relacji. Stworzenia skierowane są ku Bogu, a cechą wszystkich istot żywych jest dążenie do innego stworzenia tak, że we wszechświecie można znaleźć niezliczone, trwałe relacje, które wzajemnie się przeplatają. ${ }^{28}$ Jednym z ważnych zadań antropologii katolickiej powinno być zatem poznawanie relacji i wielu powiązań istniejących między stworzeniami, aby poszukiwać i odkrywać klucz do samorealizacji człowieka. Osoba ludzka może się bowiem rozwijać, dojrzewać i uświęcać przez wchodzenie w relacje, przekraczając $\mathrm{w}$ ten sposób siebie, aby żyć w komunii z Bogiem, z innymi osobami i ze wszystkimi stworzeniami. W ten sposób człowiek wierzący przyjmuje w swoim życiu dynamikę trynitarną, jaką Bóg w nim odcisnął od początku jego istnienia. Wszystko w stworzeniu jest połączone i dlatego to nawiązywanie coraz to nowych relacji prowadzi człowieka do dojrzewania w duchowości globalnej solidarności, która emanuje z tajemnicy Trójcy Świętej. ${ }^{29}$

26 Te n ż e, Encyklika Fides et ratio, nr 32.

27 J a n P aweł II, Przemówienie do rektorów wyższych uczelni w Polsce, Toruń 7 VI 1999, https://opoka.org.pl/biblioteka/W/WP/jan_pawel_ii/podroze/ pl-19990607_jp_uczelnie.html (dostęp: 25 III 2019), nr 5.

28 Por. Tomasz z A k w in u, Summa Theologiae I, q. 11, art. 3; q. 21, art. 1, ad 3; q. 47, art. 3.

29 Fr a n c i s ze k, Encyklika Laudato si, nr 240. 


\section{Relacja człowieka ze stworzeniem}

Natura jest często traktowana przez nowoczesnych antropologów wyłącznie jako system poznawany, analizowany i zarządzany. Natomiast antropologowie katoliccy, sięgając do nauczania Biblii, traktują „stworzenie” jako naturę ściśle związaną z Bożym planem miłości, w którym każda istota ma wartość i znaczenie. Stworzenie można zatem zrozumieć w pełni tylko jako dar kochającego Ojca, jako rzeczywistość oświetloną miłością, wzywająca każdego człowieka do powszechnej komunii i tworzenia relacji z innymi ludźmi. ${ }^{30}$

Antropologia katolicka, przede wszystkim dzięki nauczaniu Biblii, a także dzięki osiągnieciom naukowym, z których korzysta, jest wolna od ciągle ponawianych prób mitologizowania natury. Nie przestając jej podziwiać za wspaniałość i ogrom, nie przypisuje już jej charakteru boskiego. W ten sposób jeszcze bardziej podkreślone są obowiązki człowieka, istoty rozumnej i wolnej, wobec całego stworzenia. Powrót do natury nie może się jednak odbywać kosztem ograniczenia świadomości, wolności i odpowiedzialności człowieka, który jest częścią świata i ma obowiązek rozwijania swych umiejętności, aby chronić świat i rozwijać swój potencjał. Jeśli ludzie wierzący uznają wartość i kruchość natury, a jednocześnie respektują zdolności, jakie dał im Stwórca, to mogą dziś położyć kres nowoczesnemu mitowi nieograniczonego materialnego postępu, który w efekcie niszczy równowagę $\mathrm{w}$ ekosystemie i w konsekwencji zagraża samemu człowiekowi. Kruchy świat z człowiekiem, który wezwany jest przez Boga do panowania w nim, stanowi więc nowe, palące wyzwanie dla ludzkiej inteligencji, ale również dla wiary, aby osoby wierzące mogły na nowo ukierunkowywać, kształtować i ograniczać swoją władzę nad stworzeniem. ${ }^{31}$

Wspomniana wcześniej demitologizacja natury w chrześcijańskiej wizji stworzenia daje ludziom wierzącym skuteczną obronę przeciw bałwochwalstwu, czyli oddawaniu czci potęgom światowym, a także

\footnotetext{
30 Tamże, nr 76.
}

31 Tamże, nr 78. 
dostarcza argumentów przeciwko fałszywie pojętemu antropocentryzmowi nowoczesnej antropologii. Dzięki wierze w Boga Stworzyciela chrześcijanin zostaje postawiony na właściwym mu miejscu i nie dąży do bycia absolutnym władcą ziem. Brak wiary w Boga Stworzyciela prowadzi natomiast do tego, że człowiek chce ciągle na nowo narzucać rzeczywistości swoje prawa i własne interesy. ${ }^{32}$

\section{Relacja chrześcijan z innymi ludźmi}

Antropologia katolicka, której źródłem jest objawienie, Tradycja i Magisterium, ukazuje chrześcijanom możliwości udziału w realizacji planów „opatrznościowych” Boga względem całej ludzkości. Nie chodzi w tym przypadku jedynie o zaangażowanie indywidualne, ani tym bardziej indywidualistyczne, jakby rozwój był możliwy na drodze odizolowanych wysiłków każdego. Prawdziwy rozwój wymaga zaangażowania wszystkich i każdego, w szczególności członków Kościoła katolickiego. Współpraca nad rozwojem całego i każdego człowieka jest bowiem obowiązkiem wszystkich wobec wszystkich, i powinna zarazem być powszechna w całym świecie: na Wschodzie, Zachodzie, Północy i Południu lub, posługując się używanymi dziś terminami, w różnych ,światach”. Jeśli natomiast usiłuje się urzeczywistniać rozwój w jednej tylko części lub w ,jednym świecie”, czyni się to kosztem innych. Podobnie dzieje się, jeśli rozwój zaczyna się dokonywać bez uwzględnienia praw innych, co prowadzi do jego przerostów i wypaczenia. Dlatego poszczególne ludy i narody mają prawo do własnego pełnego rozwoju, który, obejmując aspekty ekonomiczne i społeczne, powinien także uwzględniać ich tożsamość kulturową i otwarcie się na rzeczywistość transcendentną. W Magisterium podkreśla się jednocześnie, że nie można traktować potrzeby rozwoju jako pretekstu do narzucania innym własnego

\footnotetext{
32 Tamże, nr 75.
} 
sposobu życia (zideologizowany totalitaryzm) czy własnej wiary religijnej (prozelityzm). ${ }^{33}$

\section{Prawdziwy, integralny antropocentryzm}

W koncepcji integralnej, katolickiej antropologii z elementami ekologicznymi należy wypracować nowy styl życia chrześcijańskiego w zgodzie z prawami natury. Współcześni katolicy są zagrożeni przez praktyczny relatywizm, charakteryzujący dzisiejszą epokę, który jest „jeszcze bardziej niebezpieczny od relatywizmu doktrynalnego". ${ }^{44}$ Kiedy istota ludzka stawia siebie w centrum, to w ostateczności daje absolutny priorytet temu, co jest doraźnie wygodne, a cała reszta staje się względna. Przyczyną relatywizmu jest wszechobecność paradygmatu technokratycznego i uwielbienia nieograniczonej ludzkiej władzy, co sprawia, że wszystko staje się bez znaczenia, jeśli nie służy ich własnym bezpośrednim interesom. Jest w tym pewna logika, która pozwala ukazać, jak różne postawy wzmacniają się wzajemnie, powodując jednocześnie degradację środowiska naturalnego i społecznego. ${ }^{35}$

Według J. Ratzingera relatywizm jest pochodną pluralizmu absolutnego opartego na ideologii laickiej, która próbuje usunąć chrześcijaństwo ze świadomości współczesnych ludzi. Według niego religię chce się zamknąć raczej w sferze prywatnej, a wówczas chrześcijanie zaczynają myśleć, że chrześcijaństwo jest tylko jednym spośród wielu głosów, a zatem i oni nie powinni wprowadzać swoich osobistych przekonań na scenę polityczną. Zjawisko to występuje dziś zarówno w Stanach Zjednoczonych, jak i w Europie Zachodniej. Relatywizacja prawdy prowadzi do swoistej schizofrenii. I tak np. katoliccy politycy, którzy prywatnie chcą być wiernymi katolikami,

33 J a n P aw e 1 II, Encyklika Sollicitudo rei socialis (30 grudnia 1987), Watykan 1987, nr 32.

34 F r a n c i s z e k, Encyklika Evangelii gaudium (24 listopada 2013), Watykan 2013, nr 80.

35 Te n ż e, Encyklika Laudato si, nr 122. 
występując publicznie są przekonani, że nie powinni przenosić swoich osobistych poglądów do sfery publicznej, tłumacząc to koniecznością przestrzegania pluralizmu. ${ }^{36}$

Kultura relatywizmu, propagowana przez nowoczesną antropologię, prowadzi do różnych patologii społecznych, takich jak: praca przymusowa, niewolnictwo za długi, porzucanie osób starszych, wykorzystywanie seksualne dzieci. Relatywizm w życiu społecznym prowadzi również do opacznego rozumienia niewidzialnej siły rynku, która ma uregulować gospodarkę nawet za cenę szkodliwego wpływu na społeczeństwo i przyrodę. Papież Franciszek stawia więc konkretne pytanie: Jeśli nie ma żadnych prawd obiektywnych ani stałych zasad, poza zaspokojeniem własnych aspiracji i doraźnych potrzeb, jakie ograniczenia może mieć handel ludźmi, organizacje przestępcze, przemyt narkotyków, handel „krwawymi diamentami” czy skórami zwierząt zagrożonych wyginięciem? To właśnie logika relatywistyczna usprawiedliwia handel organami ludzi ubogich, aby je sprzedać czy wykorzystać do badań, i stoi za odrzuceniem dzieci, ponieważ nie odpowiadają życzeniom swoich rodziców. Logika relatywizmu jest też źródłem powszechnie stosowanej zasady „użyj i wyrzuć", generującej wiele odpadów jedynie z powodu nieuporządkowanego pragnienia konsumowania więcej niż faktycznie potrzeba. Dlatego antropologia katolicka odrzuca tezę, że wystarczą programy polityczne lub moc prawa, aby zapobiec zachowaniom szkodzącym środowisku, ponieważ gdy deprawuje się kultura i nie uznaje się już żadnej prawdy obiektywnej lub powszechnie obowiązujących zasad, przepisy prawne będą rozumiane jedynie jako narzucone arbitralnie i jako przeszkody, których trzeba uniknąć. ${ }^{37}$

36 Chrześcijaństwo jest drogą, którą winniśmy podązać także pod prą! Z kard. Josephem Ratzingerem, przewodniczacym Kongregacji Nauki Wiary, rozmawiali: Marek Lehnert, Bogumit Łoziński, Marcin Przeciszewski (KAI - lipiec 2004 r.), http://niedziela.pl/artykul/1491/Chrzescijanstwo-jest-droga-ktora-winnismy (dostęp: 8 VII 2017).

${ }^{37}$ Fr a n c is z e k, Encyklika Laudato si, nr 123. 


\section{Życie chrześcijańskie zgodne z prawami natury i prawdami wiary}

Antropologia katolicka korzysta z osiągnięć współczesnych badań naukowych. Jednak antropologowie katoliccy mają świadomość, że same nauki empiryczne bez wiary nie wyjaśnią w pełni życia, istoty wszystkich stworzeń i całej rzeczywistości. Jest to niemożliwe z racji czysto metodologicznych. Jeśli badania i refleksja naukowa dokonuje się w tym zamkniętym obszarze, to zanika wrażliwość estetyczna, poezja, a także zdolności rozumu do dostrzegania sensu i celu rzeczy ${ }^{38} \mathrm{~W}$ antropologii katolickiej podstawowym źródłem jest objawienie i Magisterium. Papież Franciszek zauważa, że klasyczne teksty religijne mogą oferować sens dla wszystkich epok, mają siłę motywującą, która otwiera zawsze nowe horyzonty. Rodzi się więc zasadne pytanie: Czy jest racjonalne i rozsądne usuwanie ich w mrok jedynie dlatego, że powstały w kontekście wiary religijnej? ${ }^{39}$ W istocie naiwne jest sądzenie, że zasady etyczne można przedstawić w sposób czysto abstrakcyjny, oderwany od jakiegokolwiek kontekstu, a fakt, że pojawiają się one w języku religijnym, nie odbiera im żadnej wartości w debacie publicznej. Zasady etyczne, jakie rozum jest w stanie dostrzec, zawsze mogą powracać w różnych aspektach $\mathrm{i}$ być wyrażone $\mathrm{w}$ różnych językach, $\mathrm{w}$ tym $\mathrm{w}$ języku religijnym..$^{40}$

38 Por. t e n ż e, Encyklika Lumen fidei, nr 577: „Światłu wiary, ze względu na to, że jest ono związane z prawdą miłości, nie jest obcy świat materialny, ponieważ miłość przeżywa się zawsze w ciele i duszy; światło wiary jest światłem wcielonym, mającym źródło w świetlanym życiu Jezusa. Oświeca ono również materię, ufa w jej ład, wie, że w niej otwiera się coraz szersza droga harmonii i zrozumienia. Tym samym wiara wywiera dobroczynny wpływ na spojrzenie nauki: zaprasza ona uczonego, by pozostał otwarty na rzeczywistość z całym jej niewyczerpanym bogactwem. Wiara pobudza zmysł krytyczny, ponieważ nie pozwala, by badania zadowalały się swymi formułami, i pomaga im zrozumieć, że natura jest zawsze większa. Zachęcając do zdumienia wobec tajemnicy stworzenia, wiara poszerza horyzonty rozumu, by lepiej oświecić świat odsłaniający się przed badaniami naukowymi".

39 Te n ż e, Adhortacja apostolska Evangelii gaudium, nr 256.

40 Te n ż e, Encyklika Laudato si, nr 199. 
Z drugiej strony każde rozwiązanie techniczne, jakie nauka chciałaby wnieść w życie ludzi, będzie bezsilne w obliczu poważnych problemów świata, jeśli ludzkość zatraci swój kierunek, jeśli zapomni się o wielkich motywacjach umożliwiających współżycie, poświęcenie, życzliwość. Dlatego w katolickiej antropologii kładzie się duży nacisk na aktywność ludzi wierzących, aby żyli zgodnie ze swoją wiarą i nie zaprzeczali jej własnymi czynami. W swojej działalności powinni otwierać się na łaskę Bożą i głębiej czerpać z tego, co w ich najgłębszych przekonaniach dotyczy miłości, sprawiedliwości i pokoju. Pewną przeszkodą w realizacji tego postulatu mogą być historyczne zaszłości, kiedy to złe zrozumienie zasad ewangelicznych prowadziło czasami chrześcijan do usprawiedliwiania nadużyć w traktowaniu natury lub despotycznego panowania człowieka nad stworzeniem czy też wojen, niesprawiedliwości i przemocy. Wobec tych przejawów odejścia od Prawdy chrześcijanie, jako ludzie wierzący, powinni uznać, że w ten sposób byli niewierni względem skarbu mądrości, którego powinni strzec. Bardzo często przyczyną tego braku poszanowania dla Prawdy były ograniczenia kulturowe różnych epok, które uwarunkowywały tę świadomość własnego dziedzictwa etycznego i duchowego, dlatego to właśnie powrót do źródeł pozwala religiom lepiej reagować na bieżące potrzeby. ${ }^{41}$

Dzięki rozwojowi antropologii katolickiej ukierunkowanej ekologicznie zwiększa się natomiast świadomość ekologiczna dotycząca środowiska ludzkiego. W słusznie podejmowanych działaniach ekologicznych zaczęła wyraźniej ujawniać się troska o zachowanie naturalnego habitat różnych gatunków zwierząt zagrożonych wymarciem według zasady, że każdy z nich wnosi swój wkład w ogólną równowagę ziemi. Antropolodzy katoliccy zwracają jednak uwagę, że to człowiek jest najważniejszy i należy większą wagę przywiązywać do ochrony warunków moralnych prawdziwej ekologii ludzkiej. „Nie tylko ziemia została dana człowiekowi przez Boga, aby używał jej z poszanowaniem pierwotnie zamierzonego dobra, dla którego została mu ona dana, ale również człowiek jest dla siebie samego

${ }^{41}$ Tamże, nr 200. 
darem otrzymanym od Boga i dlatego musi respektować naturalną i moralną strukturę, w jaką został wyposażony". ${ }^{2}$

We współczesnym świecie dokonują się bardzo głębokie przemiany, a rozwiązanie globalnych wyzwań, wobec których staje rodzina ludzka w nowym tysiącleciu, domaga się uwzględnienia antropologii katolickiej i społecznej nauki Kościoła, także w wymiarze ekologicznym. We współczesnym świecie to katolicy powinni podjąć wspólne i skoordynowane działania, aby prawdziwa demokracja, oparta na wartościach, stała się rzeczywistością dla ludzi XXI w. ${ }^{43}$

Antropologia katolicka nachylona ekologicznie nie jest dzisiaj jedynie nową koncepcją integralnego opisu człowieka, jako osoby myślącej, wolnej, wierzącej, zaprzyjaźnionej z przyrodą, ale jest to dziejowa konieczność obrony człowieka przed największym zagrożeniem, jakim jest on sam. ${ }^{44}$ Narzucenie współczesnym ludziom fałszywej antropologii bez Chrystusa doprowadziło do tego, że człowiek jest uważany za absolutne centrum rzeczywistości. Ten typ myślenia zakorzenił się w nowoczesnej antropologii i sprawił, że wbrew naturze rzeczy człowiek zajął miejsce Boga, zapominając o tym, że

42 J a n P a w e 1 II, Encyklika Centesimus annus, nr 38.

43 Te n ż e, Przesłanie do uczestników VI Sesji Plenarnej Papieskiej Akademii Nauk Społecznych Demokracja i wartości (23 lutego 2000), https://opoka.org.pl/ biblioteka/W/WP/jan_pawel_ii/przemowienia/demokracja_23022000.htm (dostęp: 25 III 2019), nr 14.

44 Kultura obecna, często pozbawiona chrześcijańskich korzeni, odłącza człowieka od podstawowych wartości, a wśród nich od nadziei. Wielu współczesnych ludzi, poszukując nadziei, wierzy, że można zaspokoić tę potrzebę przelotnie i nietrwale. I tak nadzieję, ograniczoną do przestrzeni ziemskiej, zamkniętej na transcendencję, utożsamia się na przykład z rajem obiecywanym przez naukę i technikę albo z różnymi formami mesjanizmu, ze szczęśliwością natury hedonistycznej, jaką daje konsumpcjonizm, czy też urojoną i sztuczną, dostarczaną przez narkotyki, albo z pewnymi formami millenaryzmu, z oczarowaniem wschodnimi filozofiami, z poszukiwaniem ezoterycznych form duchowości, z różnymi prądami New Age; t e n ż e, Adhortacja apostolska Ecclesia in Europa, nr 10. 
to nie człowiek czyni Boga, ale Bóg czyni człowieka. Zapomnienie o Bogu doprowadziło do porzucenia człowieka i dlatego w tym kontekście otworzyła się rozległa przestrzeń do swobodnego rozwoju nihilizmu na polu filozofii, relatywizmu na polu teorii poznania i moralności, pragmatyzmu i nawet cynicznego hedonizmu w strukturze życia codziennego. ${ }^{45}$ Nowa koncepcja antropologii katolickiej nachylonej ekologicznie stwarza szanse na podjęcie działań w celu obrony człowieka, którego niezmiennym celem pozostaje podążanie na spotkanie z Chrystusem zmartwychwstałym i osiągnięcie szczęśliwego życia wiecznego.

Kościół współczesny w antropologii katolickiej zwraca się ku człowiekowi, którego Bóg stworzył i zbawił z miłości. Ta myśl stanowi centrum antropologii katolickiej, którą dzisiaj należy nieustannie rozwijać, aby stała się fundamentem nowej kultury. ${ }^{46}$ Nowa antropologia katolicka powinna brać pod uwagę bogactwa i wartości kultur dzisiejszych ludzi oraz zasiewać w nich chrześcijańskie wartości. ${ }^{47}$ W tym obszarze bardzo ważną rolę mogą spełnić polscy katolicy, na co zwrócił uwagę J. Ratzinger. „W Polsce nadal bardzo silne jest powszechne utożsamianie się z chrześcijaństwem, jako jedną z podstaw tożsamości narodu. Wartości chrześcijańskie - z pewnością nie bez wewnętrznego oporu - pozostają rękojmią tożsamości polskiego społeczeństwa, świadomości godności człowieka, słowem, siłą, która otwiera przyszłość. (...) Ojciec Święty, gdy jeszcze był arcybiskupem Krakowa - czytamy o tym w jego ostatniej książce - bardzo się troszczył o stworzenie silnej wiarą inteligencji i o jej obecność na płaszczyźnie intelektualnej i społecznej. Wydaje mi się to bardzo ważne dla Europy, i szczególnie właśnie dla Polski: rozwijać myśl filozoficzną, i to taką, która podejmuje dialog z wymogami naszych czasów, z całą empiryczną rzeczywistością, jaka nas otacza. Trzeba nie tylko dostrzegać zgodność między wiarą a współczesną wizją

45 Tamże, nr 9.

46 Te n ż e, Encyklika Fides et ratio, nr 59.

${ }^{47}$ Te n że, Przesłanie do uczestników Zgromadzenia Plenarnego Papieskiej Rady ds. Kultury Chrześcijański humanizm, nr 2. 
świata, ale także wykazać, że współczesny Kościół i świat potrzebuje dobrze uformowanej inteligencji katolickiej. Nie znam dokładnie problemów polskiego duszpasterstwa, ale ważne jest, aby polski katolicyzm, tak mocny życiem wiary, miał także tę siłę intelektualną, która podejmuje dialog z wszystkimi nurtami współczesnej myśli. Chciałbym, aby ten polski katolicyzm, nacechowany nie tylko siłą wiary, ale i siłą intelektu, mógł odegrać ważna rolę i poza Polską, w kontekście europejskim". ${ }^{48}$

\section{ks. Jan Kazimierz PRZYBYŁOWSKI}

Słowa kluczowe: antropologia katolicka; ekologia; człowiek; stworzenie; relacje

Keywords: catholic anthropology; ecology; man; creation; relations

\section{Catholic Anthropology from an Ecological Perspective. Pastoral Study in the Light of the Encyclical Laudato si Summary}

The article presents the concept of integral Catholic anthropology with ecological elements. The source of the truth about man is Revelation and the teaching of the Church. Catholic anthropology also benefits from the achievements of modern science and is also open to ecological dialogue. Both reason and faith must be used in the search for truth. Man was created as a personal entity; therefore his task is to manage creation responsibly. Man is for himself a gift received from God and must therefore respect the natural and moral structure with he is equipped. The human person is capable of establishing personal relationships and this allows him to believe in God and to live in friendship with people and with all of creation.

48 Chrześcijaństwo jest drogą, którą winniśmy podażać także pod prad! Z kard. Josephem Ratzingerem, przewodniczacym Kongregacji Nauki Wiary, rozmawiali: Marek Lehnert, Bogumit Łoziński, Marcin Przeciszewski. 